\title{
CAMBRIDGE
}

\section{Cell Commitment and Differentiation}

\section{NORMAN MACLEAN and BRIAN K. HALI}

This well-illustrated textbook is about determination and differentiation in specialized animal and plant cells. The mechanisms which underlie both processes are described, for both the embryo and the adult. Determination may occur in adult life during regeneration, wound healing, cancer formation and in the immune and blood systems, and the possible genetic basis for these events is explored, as is the influence of the cell environment, the cell surface and the pericellular-extracellular matrix. The authors are experienced teachers who saw the need for a cohesive text on this aspect of developmental and cell biology. $\quad 1987 \quad 256 p p .0521 \quad 30884 \quad 4$ Hard covers $\$ 37.50$ net $\mathbf{\$ 6 9 . 5 0}$ 0521349648 Paperback $\$ 12.95$ net $\$ 19.95$

\section{Primer of Genetic Analysis: A Problems Approach} JAMES N. THOMPSON, Jr, JENNA J. HELLACK and GERALD BRAVER

Designed as a study aid for both undergraduates and graduates, this book gives students guided instructions in problem-solving in genetics. Brief study hints introduce each chapter and are followed by extensive problems and detailed answers which address common difficulties encountered by the student of genetics. By emphasizing the basic elements of genetics the book succeeds in encouraging interpretive and analytical skills.

\section{5 pp. $\quad 0 \quad 521 \quad 33178 \quad 1 \quad$ Hard covers $\$ 22.50$ net $\$ 32.50$}

o 521337569 Paperback $\$ 7.95$ net $\$ 11.95$

\section{Molecular Foundations of Drug-Receptor Interaction}

\section{P. M. DEAN}

This book outlines comprehensively the molecular foundations of drug-receptor interaction with emphasis on insights recently gained from modern chemical theory, in particular computational chemistry. As an authorative, unique account of a developing field, it will be invaluable to those studying biomolecular interactions and drug design.

\section{1 pp. $\quad$ o $521302552 \quad \$ 45.00$ net $\$ \mathbf{\$ 7 5 . 0 0}$}

\section{Dynamics of Proteins and Nucleic Acids}

\section{J. A. MaCAMMON and S. C. HARVEY}

A self-contained introduction to the theory of atomic motion in proteins and nucleic acids. The authors describe in detail the major theoretical methods that are likely to be useful in the computer-aided design of drugs, enzymes and other molecules.

$$
1987234 \text { pp. } \quad \text { o } 521307503 \quad \$ 27.50 \text { net } / \$ 39.50
$$

\section{The Benzodiazepine Receptor}

Drug Acceptor Only or a Physiologically Relevant Part of our Central Nervous System?

\section{WALTER E. MÜLLER}

Benzodiazepines are the most commonly used psychotropic drugs, prescribed for their actions as tranquillizers, hypnotics and antiepileptics. They act in the brain by binding to specific, highly selective recognition sites. This book is the first to summarize our knowledge of these receptors for a student and professional audience. Professor Müller has written a balanced and wide-reaching account which will be useful to clinicians and researchers working with the drugs.

Scientific Basis of Psychiatry 3

$1987 \quad 192$ pp. 052130418 o $\$ 27.50$ net $\$ 49.50$

\section{Cambridge University Press}

The Edinburgh Building, Shaftesbury Road, Cambridge CB2 2RU 


\title{
CAMBRIDGE Numerical Recipes
}

The Art of Scientific Computing WILLIAM PRESS, BRIAN P. FLANNERY, SAUL TEUKOLSKY
and WILLIAM T. VETTERLING

\begin{abstract}
'Numerical Recipes is exciting and informative, and I wish it every success. It will give guidance and pleasure to novice and expert alike.' Richard L. Garwin,IBM Research Centre

'Numerical Recipes seems to match the needs of students and professional scientists far better than any other text I have seen'. Richard Muller, Professor of Physics, University of California

'Any technology company that doesn't have a few copies of this work and the accompanying diskettes is wasting the precious time of its best researchers. Both would be bargains at twice their price.'

Dr Srully Blotnick, Forbes Magazine

'Numerical Recipes is an instant 'classic', a book that should be purchased and read by anyone who uses numerical methods.' AmericanJournal of Pbysics

'The authors are to be congratulated for providing the scientific community with a valuable resource.'

The Scientist
\end{abstract}

Numerical Recipes provides a practical reference and textbook for anyone doing numerical analysis. It is not only a list of every numerical technique developed, but also a guide to those that work! The authors provide the techniques and computer programs needed for analysis and also advise on their applications. They show that the practical methods of numerical computation can be simultaneously efficient, clever, and clear.

The authors assume that the reader is mathematically literate and familiar with FORTRAN or PASCAL programming languages, but no prior experience with numerical analysis or numerical methods is assumed. The programs in the book are in ANSI- standard FORTRAN-77 for the main text, and are repeated in UCSDPASCAL. Workbooks providing sample programs that illustrate the use of each subroutine and procedure are available and the listed programs can be obtained in several machine-readable formats and programming languages.

The diskettes listed below are published by Cambridge University Press. All are $51 / 4$ " double-sided doubledensity floppy diskettes. They operate on DOS 2.0/3.0 on IBM-PC, XT, AT or IBM compatible personal computers. Technical questions, corrections and requests for information on other available formats and software products, should be directed to Numerical Recipes Software, PO Box 243, Cambridge, MA 02238, USA

818 pp. $1986 \quad 0 \quad 521308119 \quad \mathbf{s} 27.50$ net

\section{Recipe Diskettes}

$$
\begin{aligned}
& \text { o } 521309557 \text { (UCSD.PASCAL) } \mathbf{\$ 1 7 . 5 0 +} \\
& \text { VAT in UK } \\
& \text { o } 52130958 \text { l (FORTRAN-77) \$17.50 + } \\
& \text { VAT in UK }
\end{aligned}
$$

$$
\begin{aligned}
& \text { Workbooks } \\
& 236 \text { pp. } 0521309565 \text { (UCSD-PASCAL) } \\
& \text { Paperback } \$ 17.50 \text { net } \\
& 178 \text { pp. } 0521313309 \text { (FORTRAN.77) } \\
& \text { Paperback \$17.50 net }
\end{aligned}
$$

\section{Example Diskettes}
0521309549
(UCSD-PASCAL) $\$ 17.50+$
VAT in UK
0521309575 (FORTRAN-77) \$17.50 +
Full details of the books and diskettes may be obtained by writing to Sally Seed at the Cambridge address or Clay Gordon
VAT in UK in New York

\section{Cambridge University Press}

The Edinburgh Building, Shaftesbury Road, Cambridge CB2 2RU, England 32 East 57 Street, New York, New York 10022, USA. 


\section{INSTRUCTIONS TO AUTHORS}

I. Quarterly Reviews of Biophysics is the official journal of the International Union for Pure and Applied Biophysics. As such, its primary aim is to provide a forum for general and specialized communication between biophysicists working in different areas. This will normally be achieved by inviting authors who have made significant contributions to give a critical and readable account of recent progress in their special fields. Shorter and even controversial articles discussing topics of particular current interest will also be published. Suggestions for reviews can be made to the editors.

2. The style of presentation must be concise, with only key references.

3. Three copies of manuscripts are required. They should be typed in double spacing throughout, including the list of references, with a margin of $4 \mathrm{~cm}$ all round. The position of tables and illustrations should be indicated in the text. Tables and legends for illustrations should be typed on separate pages. A table of contents should be provided for printing at the head of the article. Chapter and section headings and the table of contents should conform to the style in any issue from volume 19 onwards.

4. In the text, the references should be to authors and year. When a paper cited has three or more authors the style Smith et al. (1973) should be used on all occasions. At the end of the paper, references should be listed alphabetically, with the full title of each paper, and the first and last pages. Abbreviations of journal titles should follow the World List of Scientific Periodicals. Authors should follow the example below for layout and punctuation:

Bernal, J. D. (1967). Origins of Life. London: Weidenfeld and Nicolson.

Eigen, M. (I968). New looks and outlooks on physical enzymology. Q. Rev. Biophys. I, 3-33. Swenberg, C. E. \& Geacintov, N. E. (1973). Exciton interactions in organic solids. In Organic Molecular Photophysics, vol. I (ed. J. B. Birks), pp. 489-564. London: Wiley.

5. Drawings and photographs should be of the highest possible quality. The maximum size should be A4. Explanations should as far as possible be placed in the legends. Lettering for drawings and photographs should either be on a duplicate print or on an accurately registered overlay.

6. The author will receive only one set of page proofs for correction. Fifty reprints of each review will be provided free of charge. In the case of multiple authorship these proofs and offprints will be sent to the first-named author only. One hundred additional copies may be purchased if ordered at the time proofs are returned.

\section{COPYING}

This journal is registered with the Copyright Clearance Center, 27 Congress Street, Salem, Mass. o1970. Organizations in the USA who are also registered with C.C.C. may therefore copy material (beyond the limits permitted by sections 107 and 108 of US (C) law) subject to payment to C.C.C. of the per-copy fee of $\$ 05.00$. This consent does not extend to multiple copying for promotional or commercial purposes. Code $0033^{-58} 35 / 88 \$ 5.00+.00$.

ISI Tear Sheet Service, 350 r Market Street, Philadelphia, Pennsylvania I9104, USA, is authorized to supply single copies of separate articles for private use only.

For all other use, permission must be sought from Cambridge or the American Branch of Cambridge University Press. 


\section{CONTENTS}

J. DUBOCHET, M. ADRIAN, J.-J. CHANG, J.-C. HOMO, J. LEPAULT, A. W. MCDOWALL and P. SCHULTZ Cryo-electron microscopy of vitrified specimens.

C. KORBER

Phenomena at the advancing ice-liquid interface: solutes, particles, and biological cells.

\section{FORTHCOMING REVIEWS}

R. C. BRAY

The inorganic biochemistry of Molybdoenzymes

K. E. COOPER, P. Y. GATES and R. S. EISENBERG Surmounting barriers in ionic channels

J. D. COWAN and D. H. SHARP

Neural nets

(C) Cambridge University Press 1988

\section{CAMBRIDGE UNIVERSITY PRESS}

The Pitt Building, Trumpington Street, Cambridge CB2 IRP 32 East 57th Street, New York, NY 10022, USA io Stamford Road, Oakleigh, Melbourne 3r66, Australia 